\title{
AC 2010-863: POSTER, INCORPORATING ENGINEERING DESIGN INTO ELEMENTARY SCHOOL SCIENCE CURRICULA
}

Kristen Wendell, Tufts University

Kathleen Connolly, Tufts University

Christopher Wright, Tufts University

Linda Jarvin, Tufts University

Chris Rogers, Tufts University

Mike Barnett, Boston College

Ismail Marulcu, Boston College 


\title{
Incorporating Engineering Design into Elementary School Science Curricula
}

\begin{abstract}
$\underline{\text { Abstract }}$
In this paper, we present the curricula created for our study on the impact of using engineering design to teach elementary school students science content. We consider the theoretical background that supports this endeavor, the initial set of engineering design-based science curriculum units that have been created, and the preliminary findings on the science content learning that occurs during unit enactment. The four curriculum units are Design a Musical Instrument: The Science of Sound, Design a Model House: The Properties of Materials, Design an Animal Model: Animal Studies, and Design a People Mover: Simple Machines. We used prepost tests to compare engineering-based students' science content gains to those of students using their district's regular science curriculum. The results suggest that for upper elementary students, engineering-design-based science instruction enables as much or more science learning as does traditional science instruction, and at the same time it introduces students to engineering design.
\end{abstract}

\section{$\underline{\text { Introduction }}$}

Recent investigations of the use of technological design activities as contexts for secondary school science instruction have produced promising findings. ${ }^{1,2,3}$ However, students in elementary school may be even more receptive to design-based science instruction, since children of this age have been found to exhibit less apprehension toward designerly endeavors than do adults or adolescents. ${ }^{4}$ Previous research leads to the conjecture that when elementary school children engage in design activities that require specific scientific expertise, they may make progress toward two important learning outcomes: knowledge of and skills in engineering design, ${ }^{5}$ and improved understanding of the science they use in the service of design completion. ${ }^{6}$ In this paper, we describe a curriculum research and development project devoted to exploring this hypothesis. We consider the theoretical background that supports this endeavor, the initial set of four engineering design-based science curriculum units that have been created, and the preliminary findings on the science content learning that occurs during unit enactment.

The purpose of our project is to explore an overarching research question: what are the consequences of using engineering-design-based activities as contexts for specific science content instruction in the upper elementary grades? To investigate this question, we have collaborated with local teachers to develop and implement four engineering-design-based science curriculum units for third- and fourth-grade classrooms. In engineering-design-based science, students engage in scientific investigations to deepen their understanding of a design problem's constraints or potential solutions. The process of solving the design problem provides opportunities for students to learn and apply new science concepts and practices. For example, to tackle the design challenge of constructing a musical instrument, students must understand the relationship between an object's physical characteristics and the sound it produces. 
The incorporation of engineering design into science curriculum is supported by the National Academy of Sciences, which reports that the number of students who have had formal engineering education since 1990 is less than 6 million, whereas the number of students enrolled in U.S. K-12 classrooms was about 56 million in $2008 .^{7}$ This means that less than 10 percent of students between 1990 and 2008 have had some type of formal engineering education. The National Academy of Sciences documents the potential benefits of including engineering education in $\mathrm{K}-12$ schools as (a) improved learning and achievement in science and mathematics, (b) increased awareness of engineering and the work of engineers, (c) understanding of and the ability to engage in engineering design, (d) interest in pursuing engineering as a career, and (e) increased technological literacy. ${ }^{7}$ However, the National Academy of Sciences also reports the lack of reliable data to support those potential benefits of teaching engineering education to K-12 students. The academy recommends that long-term research that explores the impact of engineering education on students' learning of STEM subjects and technological literacy, student engagement and retention, and career aspirations should be supported.

\section{$\underline{\text { Literature Review }}$}

\section{Existing Approaches To Design-Based Science for Children}

Currently, there is limited research literature that attempts to explain how the design-based science approach impacts young students' learning of content and practices specific to a single domain in science. While many studies have examined how older students $\left(5^{\text {th }}\right.$ through $12^{\text {th }}$ grade) engage in science through design problems, $8,9,10,11$ only Roth ${ }^{12}$ and Penner and colleagues ${ }^{13}$ have studied in detail the science-through-design learning of children age 10 and younger. Other scholars have looked at young children's designing and building abilities and their knowledge of technological design, 4,14,15,16,17,18 but they have not investigated children's learning of science through such design activities.

Despite these limitations, there remains a great deal of interest in incorporating engineering design into elementary school science. ${ }^{19,20,21}$ As we reviewed the literature, we asked, what is the basis for this sustained interest? Do empirical studies and cognitive theory give educators reason to conclude that engineering design tasks can truly foster science learning? In Table 1, we review three approaches to design-based science instruction at the elementary and middle school level in North America: design-based modeling by Penner, Giles, Lehrer, and Schauble, ${ }^{13}$ engineering for children by Roth, ${ }^{12}$ and Learning by Design TM by Kolodner and colleagues. ${ }^{2}$ We focus on these approaches because they are representative of the field, and because information is available about their theoretical background, their principles of curriculum design, and their findings on learning.

A variety of science content areas have been addressed through these three approaches to designbased science instruction. The design tasks chosen to situate the science content also span a wide range. However, all three of these approaches understand design as an activity whose goal is the construction of a physical product. In all of the approaches, students are initially tasked with creating a functioning device or system that serves a purpose established by the instructor. The resulting construction is then considered an essential factor in students' learning. For Penner and 
colleagues, ${ }^{13,22}$ the designed constructions enable model-based reasoning, deeper investigation of science concepts, and exploration of mathematical relationships. Roth ${ }^{12}$ sees each design construction as a tool to think with, a representation of cognitive processes, and a backdrop for class discussion and sense-making. Finally, in Kolodner's work, ${ }^{10}$ the challenge of creating a functioning product provides motivation and opportunities for scientific reasoning and learning.

Table 1. Three Representative Approaches to Design-Based Science in Elementary or Middle School

\begin{tabular}{|c|c|c|c|c|}
\hline $\begin{array}{l}\text { Approach and } \\
\text { Authors }\end{array}$ & $\begin{array}{l}\text { Sample Design } \\
\text { Task and } \\
\text { Associated Science } \\
\text { Concepts }\end{array}$ & Findings on Learning & $\begin{array}{l}\text { Main } \\
\text { Contribution of } \\
\text { Approach }\end{array}$ & $\begin{array}{l}\text { Challenges of } \\
\text { Implementing the } \\
\text { Approach }\end{array}$ \\
\hline $\begin{array}{l}\text { Design-Based } \\
\text { Modeling } 13,22 \\
\text { (Penner, } \\
\text { Lehrer, \& } \\
\text { Schauble, } \\
\text { 1997; Penner, } \\
\text { Giles, Lehrer, } \\
\text { \& Schauble, } \\
\text { 1998) }\end{array}$ & $\begin{array}{l}\text { For 6- to 9-year- } \\
\text { olds } \\
\text { Task: Design a } \\
\text { model of the } \\
\text { human elbow. } \\
\text { Learn: Importance } \\
\text { of constraints on } \\
\text { motion, arm as 3rd- } \\
\text { class lever, math } \\
\text { relationships within } \\
\text { levers, modeling in } \\
\text { general. }\end{array}$ & $\begin{array}{l}\text { Mainly science process- } \\
\text { oriented learning. } \\
\text { Improved recognition of the } \\
\text { importance of a model's } \\
\text { functional qualities. } \\
\text { Minimal gains in } \\
\text { understanding the arm as } \\
\text { lever. }\end{array}$ & $\begin{array}{l}\text { Design skills can } \\
\text { be improved } \\
\text { simultaneously } \\
\text { with science } \\
\text { process skills } \\
\text { and } \\
\text { understanding. }\end{array}$ & $\begin{array}{l}\text { Difficult to move } \\
\text { children from } \\
\text { summarizing patterns } \\
\text { of artifact } \\
\text { performance to } \\
\text { explicit } \\
\text { understanding of the } \\
\text { underlying science } \\
\text { principles. }\end{array}$ \\
\hline $\begin{array}{l}\text { Engineering } \\
\text { for } \\
\text { Children }{ }^{12,23,24} \\
\text { (Roth, 1996, } \\
\text { 1997, 2001) }\end{array}$ & $\begin{array}{l}\text { For 9- to 12-year- } \\
\text { olds } \\
\text { Task: Design a } \\
\text { strong tower from } \\
\text { common materials. } \\
\text { Learn: Stability, } \\
\text { shapes, forces. } \\
\text { Task: Build a } \\
\text { machine that uses } \\
\text { simple machines. } \\
\text { Learn: Physics of } \\
\text { simple machines. }\end{array}$ & $\begin{array}{l}\text { Six kinds of learning, } \\
\text { almost all process-oriented: } \\
\text { (1) dealing with complex, } \\
\text { open-ended tasks, (2) new } \\
\text { meanings for materials and } \\
\text { artifacts, (3) being } \\
\text { conscious of participation in } \\
\text { design, (4) negotiating with } \\
\text { classmates, (5) using a } \\
\text { variety of tools in } \\
\text { interesting ways, (6) } \\
\text { communicating about } \\
\text { design. }\end{array}$ & $\begin{array}{l}\text { Main emphasis is } \\
\text { on classroom } \\
\text { discourse } \\
\text { (talking and } \\
\text { writing). In order } \\
\text { for science } \\
\text { learning to } \\
\text { occur, discourse } \\
\text { must hold as } \\
\text { much weight as } \\
\text { designing. }\end{array}$ & $\begin{array}{l}\text { Open-ended, no clear } \\
\text { instructional } \\
\text { sequence or } \\
\text { definition of what } \\
\text { constitutes a good } \\
\text { design task; the } \\
\text { effectiveness of the } \\
\text { design context } \\
\text { depends on the } \\
\text { individual teacher. }\end{array}$ \\
\hline $\begin{array}{l}\text { Learning by } \\
\text { Design TM } \\
2,10 \\
\text { (Kolodner et } \\
\text { al., 2003; } \\
\text { Kolodner, } \\
\text { 2006) }\end{array}$ & $\begin{array}{l}\text { For 11- to 14-year- } \\
\text { olds } \\
\text { Task: Design an } \\
\text { optimal balloon- } \\
\text { powered coaster } \\
\text { car } \\
\text { Learn: Basic } \\
\text { mechanics, } \\
\text { Newton's laws of } \\
\text { motion }\end{array}$ & $\begin{array}{l}\text { Both process-oriented and } \\
\text { conceptual learning were } \\
\text { measured. LBD students } \\
\text { showed higher gains than } \\
\text { matched peers on multiple } \\
\text { choice pre-post tests, and } \\
\text { better performance in } \\
\text { designing experiments, } \\
\text { planning data collection, } \\
\text { and collaborating. }\end{array}$ & $\begin{array}{l}\text { Recognize that } \\
\text { classroom } \\
\text { culture } \\
\text { conducive to } \\
\text { design is not } \\
\text { created } \\
\text { automatically, } \\
\text { and specify } \\
\text { "ritualizing } \\
\text { practices" to help } \\
\text { construct culture. }\end{array}$ & $\begin{array}{l}\text { Conceptual learning } \\
\text { is highly dependent } \\
\text { on teacher } \\
\text { competency and } \\
\text { attitudes. Some } \\
\text { teachers leave } \\
\text { program because they } \\
\text { are not able to adjust } \\
\text { to a new kind of } \\
\text { classroom control. }\end{array}$ \\
\hline
\end{tabular}

Across these three approaches, there are several commonalities in how classroom instructional practice is structured. All students work in groups, and interaction among students and improvement of communication skills are key goals of the teacher. As they work on solving the design problem, students are always expected to engage in written or pictorial record-keeping. At 
some point, students are given the option to revise their designs. In addition to their individual record-keeping and reflection, students reflect on their designing through participation in wholeclass discussions. Importantly, throughout design-based science units, teachers provide guidance on how students should incorporate science ideas and careful reasoning into their design solutions. Researchers believe that this scaffolding is essential for preventing students from merely tinkering.

\section{The Theoretical Basis for Design-Based Science Curriculum}

The notion that engineering design problems can foster science learning is supported by the theoretical perspectives of situated cognition and distributed cognition. From a situated cognition perspective, ${ }^{25,26}$ we can describe engineering design as a sociocultural activity which situates the use of science concepts and thus lend everyday meaning to them. The situated cognition view of learning, which is consistent with Vygotsky's insistence on the sociocultural nature of learning, asserts that an individual's cognition is embedded in and inseparable from the individual's situation and activity in a community of practice. ${ }^{25}$ In other words, concepts are always enmeshed with culture and activity, and the meaningfulness of learning is constrained by all three conditions. We posit that engineering design is one kind of activity that requires both the use of science practices and science content knowledge.

The theoretical basis provided by situated cognition theory is strengthened by the theory of distributed cognition. ${ }^{27,28}$ During an engineering design activity, an individual's knowledge about related science concepts can be unloaded to the tangible design products as well as to the other people participating in the design process. This sharing of knowledge may be one example of distributed cognition, which Bell and $\mathrm{Winn}^{29}$ define as a person's individual cognitive acts plus the augmentation of other people, external devices, and cultural tools. In other words, the notion of distributed cognition implies that cognition includes both the social and physical environments. From a distributed cognition point-of-view, we can propose that engineering design may spread the cognitive load of achieving scientific understanding among design products (artifacts), design teammates (classmates), and design coaches (teachers), thereby augmenting the individual student's capacity for science learning.

\section{Curriculum Development: Science through LEGO}

Our program's approach to incorporating engineering design problems into elementary-grade science instruction reflects the theoretical perspectives of situated and distributed cognition, and it also draws heavily upon the Learning by Design ${ }^{\mathrm{TM}}$ approach to middle-school science ${ }^{10}$. Other previous teaching experiments, including those of Roth, ${ }^{12}$ Penner et al., ${ }^{13}$ Grigorenko, Jarvin, and Sternberg, ${ }^{30}$ Sadler et al., ${ }^{11}$ Krajcik et al., ${ }^{31}$ and Crismond, ${ }^{8}$ also influenced our work, and we synthesized what we learned from theory and research into two sets of curriculum development principles. We created the first set of development principles, detailed in Table 2, before beginning any curriculum writing. Our second set of principles for curriculum development, shown in Table 3, emerged as we conducted the first cycle of curriculum writing, testing, and revising. Both sets of principles provided guidance for our creative efforts. 
Table 2. Original Curriculum Development Principles

\begin{tabular}{|c|c|}
\hline Principle & Description \\
\hline $\begin{array}{l}\text { 1. Engineering Context } \\
\text { \& Science Content }\end{array}$ & $\begin{array}{l}\text { The context for instruction will always consist of engineering design challenges with } \\
\text { (a) clear ties to lives of students and (b) solutions that require understanding of specific } \\
\text { science content standards. }\end{array}$ \\
\hline $\begin{array}{l}\text { 2. Authentic Definition } \\
\text { of Engineering }\end{array}$ & $\begin{array}{l}\text { "Engineering" will be defined as the process of designing and prototyping a tangible } \\
\text { solution, or the model of a solution, to an authentic human problem. Engineering is not } \\
\text { simply the use of technology, but the creation or use of it for the purpose of addressing } \\
\text { a human need or want. }\end{array}$ \\
\hline $\begin{array}{l}\text { 3. AAAS Project } 2061 \\
\text { Criteria }\end{array}$ & $\begin{array}{l}\text { The units will meet the seven criteria for curriculum set forth by Project } 2061 \text { of the } \\
\text { American Association for the Advancement of Science: }{ }^{32} \\
\text { Providing a Sense of Purpose, Taking Account of Student Ideas, Engaging Students with Relevant } \\
\text { Phenomena, Developing and Using Scientific Ideas, Promoting Students'Thinking about Phenomena, } \\
\text { Experiences, and Knowledge, Assessing Progress, and Enhancing the Science Learning Environment. }\end{array}$ \\
\hline $\begin{array}{l}\text { 4. Teachers' } \\
\text { Feasibility and } \\
\text { Usability Concerns }\end{array}$ & $\begin{array}{l}\text { The units will be tailored to concerns about feasibility and usability voiced by teachers } \\
\text { during our pre-proposal focus group and interviews. These concerns include the need } \\
\text { for specific classroom management procedures and the requirement that lessons be } \\
\text { woven into the district-mandated science schedule. }\end{array}$ \\
\hline 5. Triarchic Instruction & $\begin{array}{l}\text { In accordance with Sternberg's theory of triarchic intelligence, the units will tap into } \\
\text { students' creative and practical cognitive abilities in addition to their memory and } \\
\text { analytical abilities. }\end{array}$ \\
\hline 6. Standards Based & $\begin{array}{l}\text { The units will be focused on standards-based learning objectives, aligned with both the } \\
\text { National Science Education Standards }{ }^{34} \text { and the Massachusetts Science and } \\
\text { Technology/Engineering Curriculum Framework. }\end{array}$ \\
\hline
\end{tabular}

Table 3. Emergent Curriculum Development Principles

\begin{tabular}{ll}
\hline Principle & Description \\
\hline A. Materials First & $\begin{array}{l}\text { Provide opportunity to learn how to use LEGO construction materials before the } \\
\text { science unit begins. }\end{array}$ \\
\hline B. Challenge Second & $\begin{array}{l}\text { Present the grand engineering design challenge at the very beginning of the science } \\
\text { unit. }\end{array}$ \\
\hline $\begin{array}{l}\text { C. Science Inquiry as } \\
\text { Design Research }\end{array}$ & $\begin{array}{l}\text { Use scientific investigations of student-constructed artifacts as the "research" for the } \\
\text { planning, building, and testing of designs to solve the grand design challenge. }\end{array}$ \\
\hline $\begin{array}{l}\text { D. Student Dyads } \\
\text { Arrange students in pairs for all engineering challenges and scientific investigations. } \\
\text { (With triads, one student is often unengaged. Working alone, students have few } \\
\text { opportunities to articulate their reasoning. Dyads are optimal for } 3^{\text {rd }} / 4^{\text {th }} \text { grade students.) }\end{array}$ \\
\hline $\begin{array}{l}\text { E. Student-Generated } \\
\text { Representations }\end{array}$ & $\begin{array}{l}\text { Prompt students to generate written, pictorial, and oral representations of their thinking } \\
\text { at all stages of design and investigation. }\end{array}$ \\
\hline $\begin{array}{l}\text { G. Critical Student } \\
\text { Perspective }\end{array}$ & $\begin{array}{l}\text { Encourage critical analysis of strengths and weaknesses of LEGO constructions as } \\
\text { models. }\end{array}$
\end{tabular}

We followed a two-phase process to develop the curriculum units. The first phase involved teacher focus groups, coordination with school district personnel, and identification of target science domains (i.e., unit topics). The second phase began once the four unit science domains had been chosen. This phase entailed creating standards-based learning objectives for each unit; devising unit storylines; crafting lesson plans, physical artifact samples, and student journal 
pages; and finally, pilot-teaching and revising. Table 4 details the entire curriculum development process.

Table 4. Curriculum Development Process

Phase A: Steps taken before selecting unit science domains

1. Hold focus groups with elementary teachers about their concerns and needs regarding science instruction.

2. Meet with school district science coordinator to determine target grade levels and science domains.

3. Narrow to two target science domains per grade level (material properties and sound in $3^{\text {rd }}$ grade; simple machines and animal adaptations in $4^{\text {th }}$ grade).

Phase B: Steps take for each chosen science domain

1. Consult national, state, and local standards of learning to determine a set of 8 to 10 specific science and engineering learning objectives.

2. Establish an overarching engineering challenge that lends itself well to science investigations related to the learning objectives.

3. Create a unit "storyline": a sequence of activities that provide opportunities to meet the science learning objectives while simultaneously preparing students for success at the overarching engineering challenge.

4. Write formal lesson plans and student journal pages that enable teacher and students to follow the unit storyline in 9 to 11 lessons.

5. Create necessary supplemental resources: building instructions for artifacts needed for scientific investigations, background reading for teachers, and photographs of experimental set-ups.

6. Pilot teach the unit with a class of students.

7. Solicit feedback from pilot class's regular teacher.

8. Revise all lesson plans and journal pages.

\section{Overview of the Science through LEGO ${ }^{\mathrm{TM}}$ Engineering Curriculum}

The four curriculum units that we have developed are intended for third- and fourth-grade (8- to 11-year-old) students. Each unit poses an overarching engineering design challenge as a motivator for science investigations, uses interlocking (LEGO ${ }^{\mathrm{TM}}$ ) construction elements for prototyping, requires approximately 12 hours of instructional time, and addresses a particular science domain. The Design a Musical Instrument unit centers on the science of sound, Design a Model House focuses on the properties of materials and objects, Design an Animal Model emphasizes the structural and behavioral adaptations of animals, and Design a People Mover focuses on the force-distance trade-offs of simple machines. The units' learning objectives are aligned with local and national standards of science learning.

\section{Common Aspects Of All Units}

Before beginning a unit proper, teachers enact two introductory lessons that are the same for all four units. The goal of these preparatory lessons is to introduce students to engineering and to learning with LEGO ${ }^{\mathrm{TM}}$ materials. After sharing their initial ideas about what engineering is, students are presented with a definition of engineering and a five-step model of the engineering design process (see Figure 1). Next, they are invited to classify items as "engineered" (e.g., a light bulb) or "probably not engineered" (e.g., a tree), and finally, they are given time to explore basic LEGO ${ }^{\mathrm{TM}}$ construction techniques. After these experiences, teachers launch into one of the science curriculum units. 
Each science unit follows approximately the same instructional pattern, which entails a series of 9 to 11 lessons that are designed to require one hour of instructional time. As illustrated in Figure 1 , the unit pattern roughly approximates one cycle through the engineering design process. The "find a problem" step occurs first: the first lesson in each unit focuses on specifying the grand engineering design challenge and the big science question for the unit. Students write about and discuss what they already know that will help them complete the challenge and answer the question, and they identify what they still need to learn. The "research possible solutions" step of the engineering design process comes next: in the next six to eight lessons of each unit, students carry out "mini design challenges" and "mini science investigations" to learn the knowledge and skills that will enable success on the grand design challenge. Most of the mini challenges and investigations involve the construction and testing of physical artifacts. Along the way, teachers guide students in reflecting on how their findings will inform the step of "choosing the best solution." Finally, the "build a prototype," and "test the prototype" steps take place: in the last two to three lessons of each unit, students build, test, and improve their solution to the grand design challenge, and then present to their classmates an explanation of how it works.

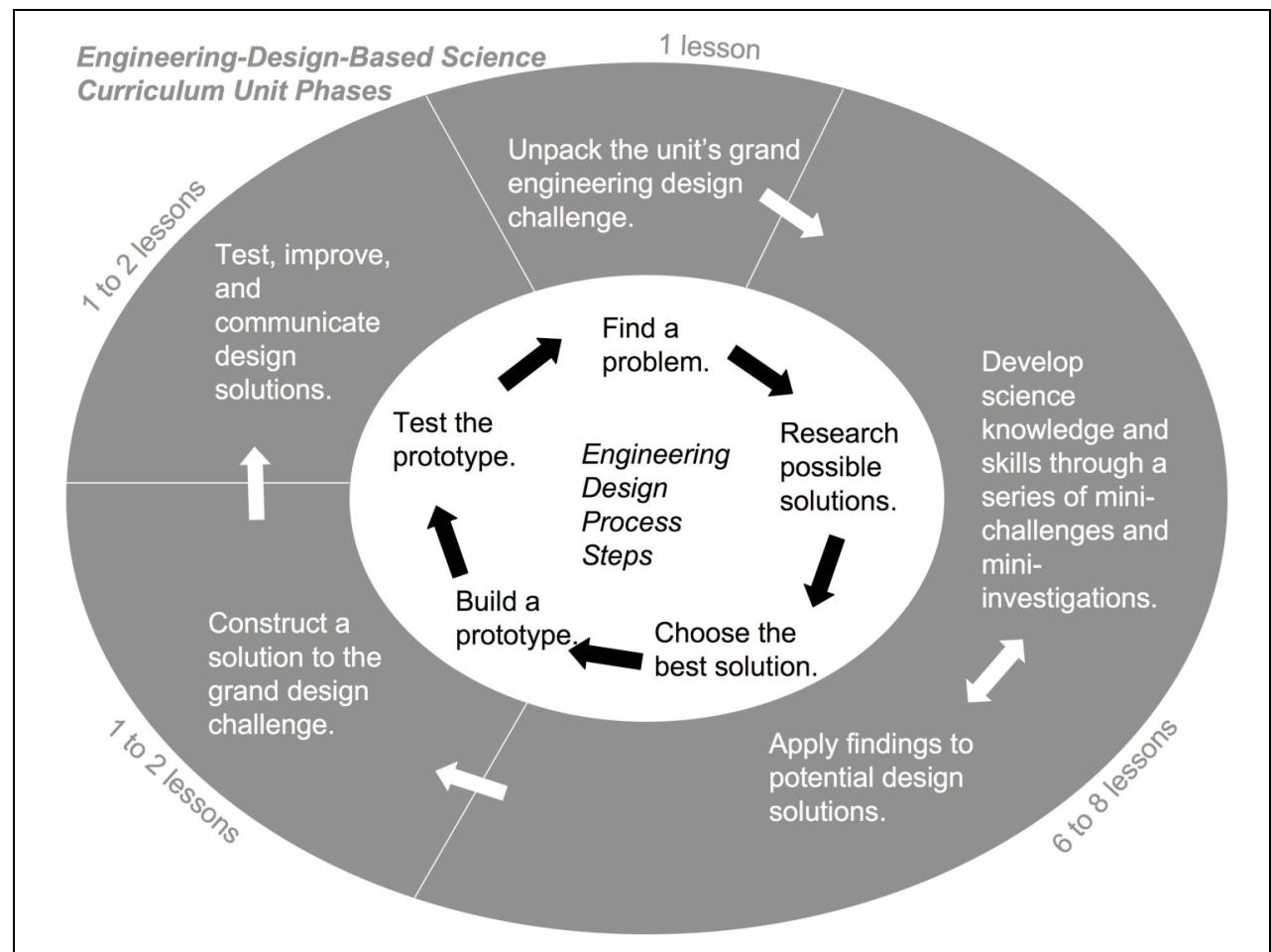

Figure 1. Instructional pattern for our Science through LEGO ${ }^{\mathrm{TM}}$ Engineering units, compared to a simplified model of the engineering design process

Just as each overall unit follows the same pattern, each individual lesson is designed to follow a similar flow of events. The teacher initiates each lesson by revealing the goal of the inquiry (mini-challenge or mini-investigation) to be completed that day. Then, students work independently for five minutes to respond to a brief brainstorming prompt - called an exploration question - related to that goal. Next, students work in pairs on the mini-challenge or mini-investigation. They find instructions for building and prompts for testing and observing in their Engineer's Journal, a workbook text that is provided with the unit materials. The lesson 
concludes with a teacher-led, whole-class discussion about how the lesson's experiences provided new knowledge or skills that will be useful for the grand design challenge.

\section{Common Materials For All Units}

Teachers and students are provided with the same general set of tools for each unit. These include a) a teacher's guide, b) a student workbook that we call an Engineer's Journal, c) a written science content assessment, d) an assortment of common craft materials, and e) a kit of LEGO $^{\mathrm{TM}}$ construction elements and electronic sensors for each student pair. The assessment will be discussed in a later section; the other tools are described below.

The teacher's guide is intended both to specify lesson enactment and to support growth in the teacher's science and pedagogical content knowledge. For each lesson, the guide includes eight sections: learning objectives, background information about the science content, typical preconceptions held by students, key vocabulary terms, materials to be gathered, preparation steps to be taken before the lesson, procedure for instruction, and tips for assisting students with building and testing.

The student Engineer's Journal is a paper-and-pencil tool that guides the students through the unit's engineering design process. For each of the nine to eleven lessons in a unit, the journals provide introductory open-response questions, building and observation instructions, data recording prompts, and reflection questions. The prompts and questions ask for writing, drawing, and numerical inscriptions, and each is an opportunity for students to record their emerging content knowledge and practice skills related to the unit's science domain.

The rationale for using a combination of $\mathrm{LEGO}^{\mathrm{TM}}$ tools and craft materials, instead of craft materials only, is that the interlocking building elements in the LEGO ${ }^{\text {TM }}$ toolset have a low "cost" of prototyping and re-design. ${ }^{15}$ Because the LEGOTM elements do not require any assembly tools (such as glue, tape, staples, or scissors) students can quickly create a first prototype. Also unlike glue, tape, or staples, the fastening mechanisms for LEGO ${ }^{\mathrm{TM}}$ pieces are sturdy but always temporary, so students can quickly reverse an action and move pieces around to change a design. Another reason for selecting the LEGO ${ }^{\mathrm{TM}}$ toolset is that its building elements are compatible with microprocessors and electronic sensor probes, and this allows for the interweaving of design challenges and science investigations. Finally, the LEGO ${ }^{\text {TM }}$ toolset is a one-time investment that lasts for many years without the need for re-supply, and it is perceived by students to be a novel and motivating tool for science learning. ${ }^{20}$

\section{Unit Synopses}

The sound unit. In the opening lesson of the Design a Musical Instrument: The Science of Sound curriculum unit, students learn that their engineering design challenge is to create a new musical instrument that can play at least three different notes and contribute to a classroom band. Over the next six lessons, students conduct a series of guided design-based investigations to explore how sounds are produced, transmitted, and varied across different sound producers. Using LEGO $^{\mathrm{TM}}$ construction kit elements and additional craft materials, they build a miniature drum, pan pipe, rubber-band guitar, and maraca. They explore the structural design of these 
instruments, observe how they look and sound when played, and identify the characteristics of the sounds they make. As students build and investigate these instruments, they are asked to explain scientifically how physical characteristics are connected to sound characteristics. For example, how does the size of an object influence the pitch of the sound it makes? Throughout the unit, students are encouraged to consider how these relationships between physical and aural characteristics can inform their design of a new musical instrument. In the unit's two concluding lessons, students employ their new understanding of sound to design, construct, and demonstrate musical instruments of their own invention (see Figure 2). They also demonstrate what they have learned about the unit's big science question: How are sounds made?

As a sample for all four units, Appendix A shows the sound unit's alignment with national and state learning standards, and Appendix B provides a content analysis of the unit.

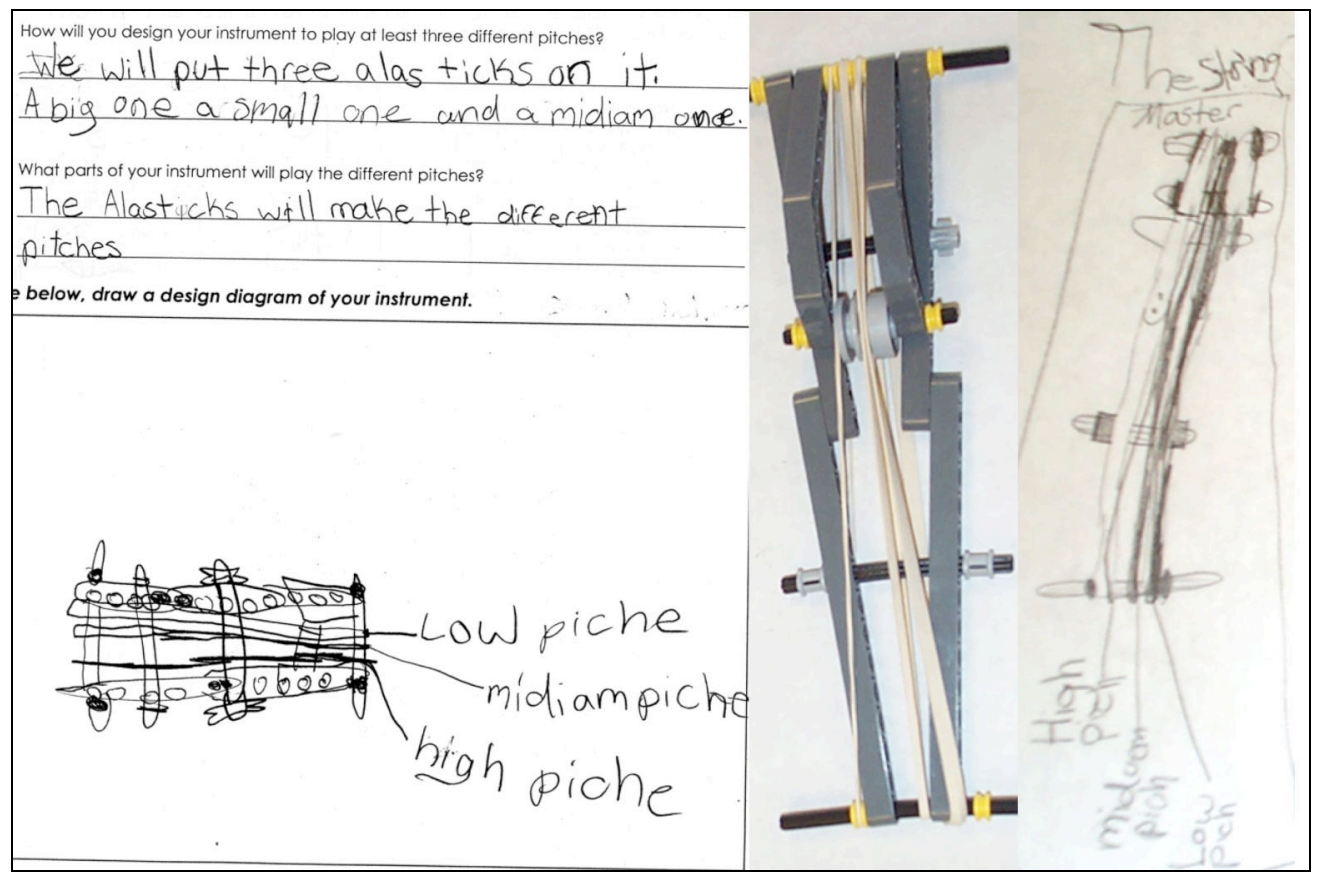

Figure 2. A third-grader's musical instrument design plans and corresponding three-pitch musical instrument

The properties of materials unit. The Design a Model House: The Properties of Materials unit begins with students' learning that their engineering design challenge is to create a miniature model house that is stable, soundproof, and thermally insulated. Over the next six lessons, the students conduct a series of engineering tests to identify materials to meet these design requirements. They compare clay and $\mathrm{LEGO}^{\mathrm{TM}}$ construction elements for their house frames, and they test quilt batting, polyurethane foam, cardboard, and transparent acrylic as choices for the house wall and roof surfaces. They use the LEGO ${ }^{\mathrm{TM}}$ microprocessor and digital sound and temperature sensors as instruments for testing. As the students test materials and begin prototyping, they are asked to make scientific arguments about the best materials for each portion of the house. They are encouraged to consider the material and object properties of stability, strength, soundproofing, insulation, and reflectivity. In the unit's two concluding 
lessons, the students employ their new understanding of object and material properties to complete the design and building of their miniature model houses (see Figure 3 ). The big science question of this unit is, How can we describe and choose objects and materials?

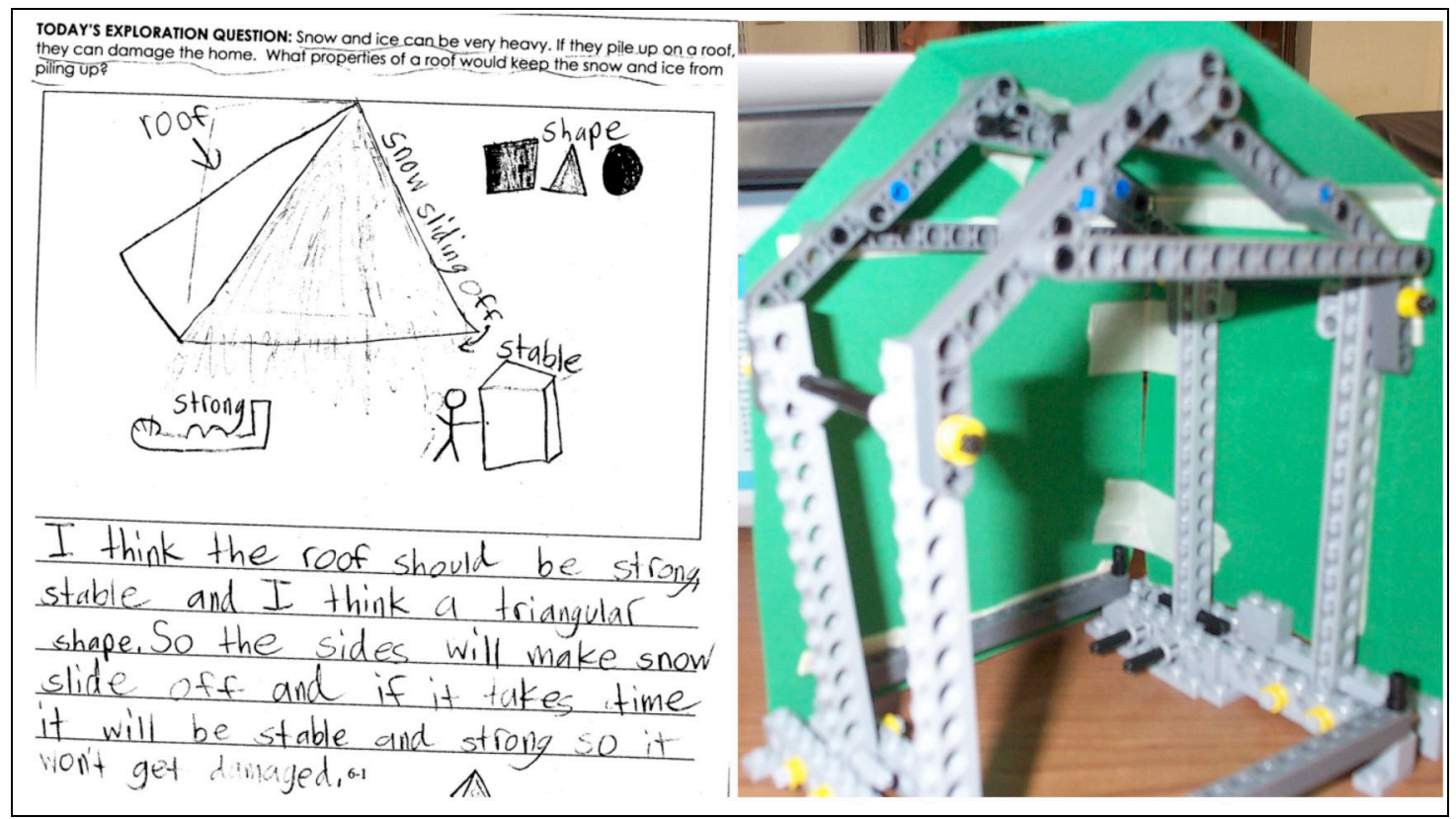

Figure 3. A third-grader's reflection on the important properties of a roof and subsequent stable, insulated model house

The animals unit. The Design an Animal Model: Animal Studies curriculum unit is intended to help students explore the structural and behavioral adaptations of animals. In the first lesson of the unit, students discover that their grand design challenge is to design a believable but "newly discovered" animal to be featured in a fictional adventure movie set in a tropical rainforest. To complete the challenge, they must build a movable model of the animal's structures as well as a robotic model of its behaviors. After the opening lesson, the first phase of the unit focuses on introducing students to the tools and practices that animal biologists use, including species classification, habitat research, and field study. Then, in the fifth through eighth lessons, students learn about and practice constructing two kinds of models of animals: mechanical models of animal structures (e.g., a jointed model of a frog's leg or a crab's claw), and computer-controlled models of animal behaviors. Students apply their observations of real animal structures to construct movable LEGO models. With substantial teacher support, students apply their observations of live animal behavior to write computer programs that control LEGO motors and sensors to enact stimulus-response rules. Finally, in the concluding phase of the Design an Animal Model unit, each pair of students works independently to propose and model a "newly discovered" species that would be well-adapted to survive in the tropical rainforest ecosystem (see Figure 4). This challenge is designed to help students construct an answer to the unit's big science question: Why do animals look and act the way they do, and how can we study and explain their looks and actions? 


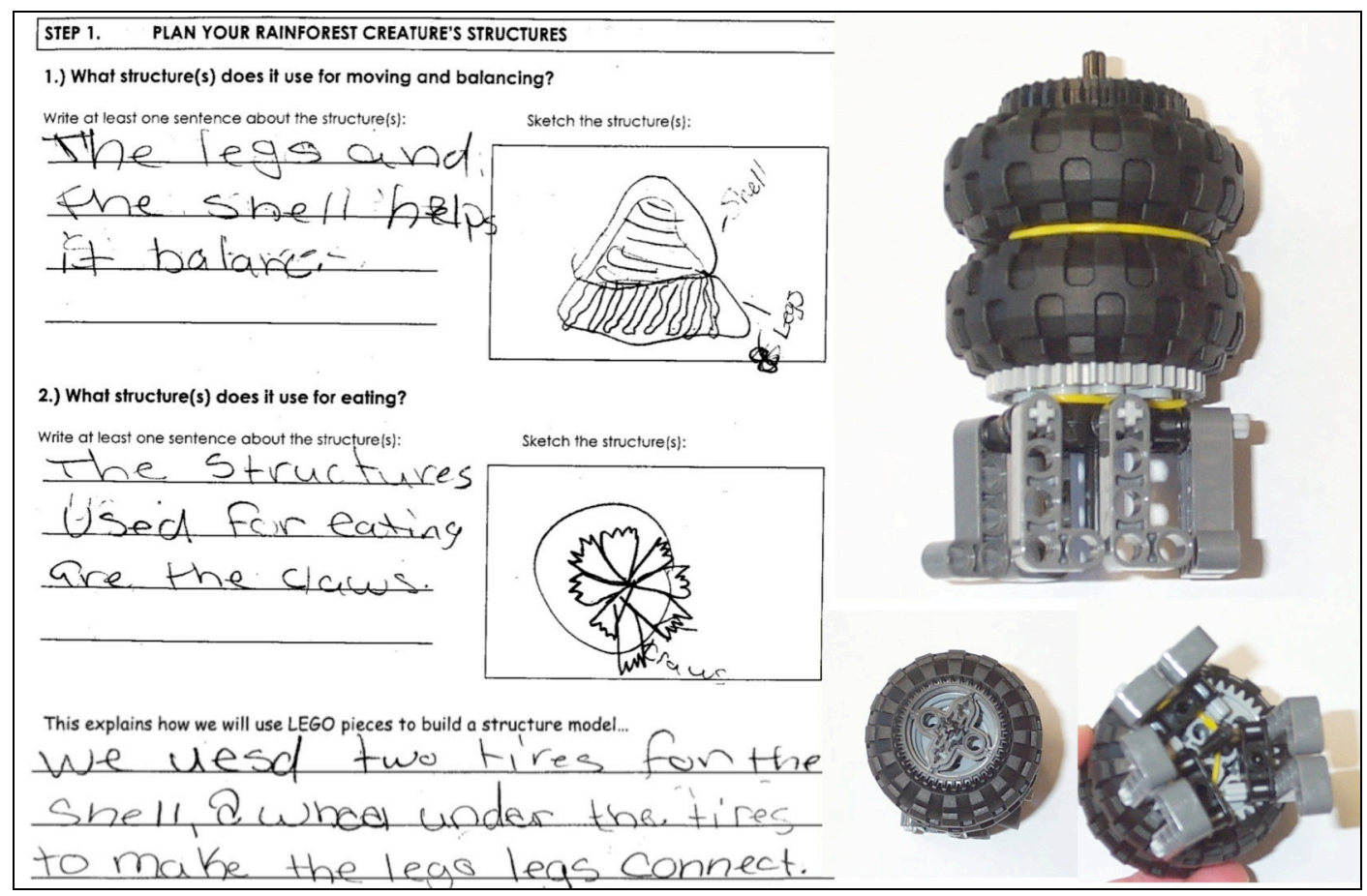

Figure 4. A fourth-grader's analysis of a crab-like animal's structures and the resulting structural animal model

The simple machines unit. At the start of the Design a People Mover: Simple Machines curriculum unit, students find out that their grand engineering challenge is to design and build a model of an airport "people mover" machine - a new device that can move people up and across surfaces safely and quickly. In the subsequent seven lessons, students investigate seven types of simple machines (lever, inclined plane, wedge, screw, wheel-and-axle, pulley, and gear) by building a LEGO ${ }^{\mathrm{TM}}$ version and then using it to accomplish some physical task. For example, they build a LEGO ${ }^{\mathrm{TM}}$ lever to lift a small load, a LEGO ${ }^{\mathrm{TM}}$ egg beater (with wheel-and-axle system) to mix a bowl of beans, and a miniature LEGO ${ }^{\mathrm{TM}}$ pulley to hoist a small weight. With each simple machine, they make several small adjustments to designs that allow them to explore the trade-off between reducing the input force and increasing the distance over which the force must be exerted. In the ninth lesson, students practice identifying simple machines within complex machines. Finally, in the culminating two lessons, students work independently on the open-ended task of planning, constructing, and testing their own complex machine (with at least three identifiable simple machines) that functions as a miniature people-mover. The goal of this series of learning experiences is for students to be able to answer the unit's big science question: How can we design simple machines to be most helpful for doing work? 


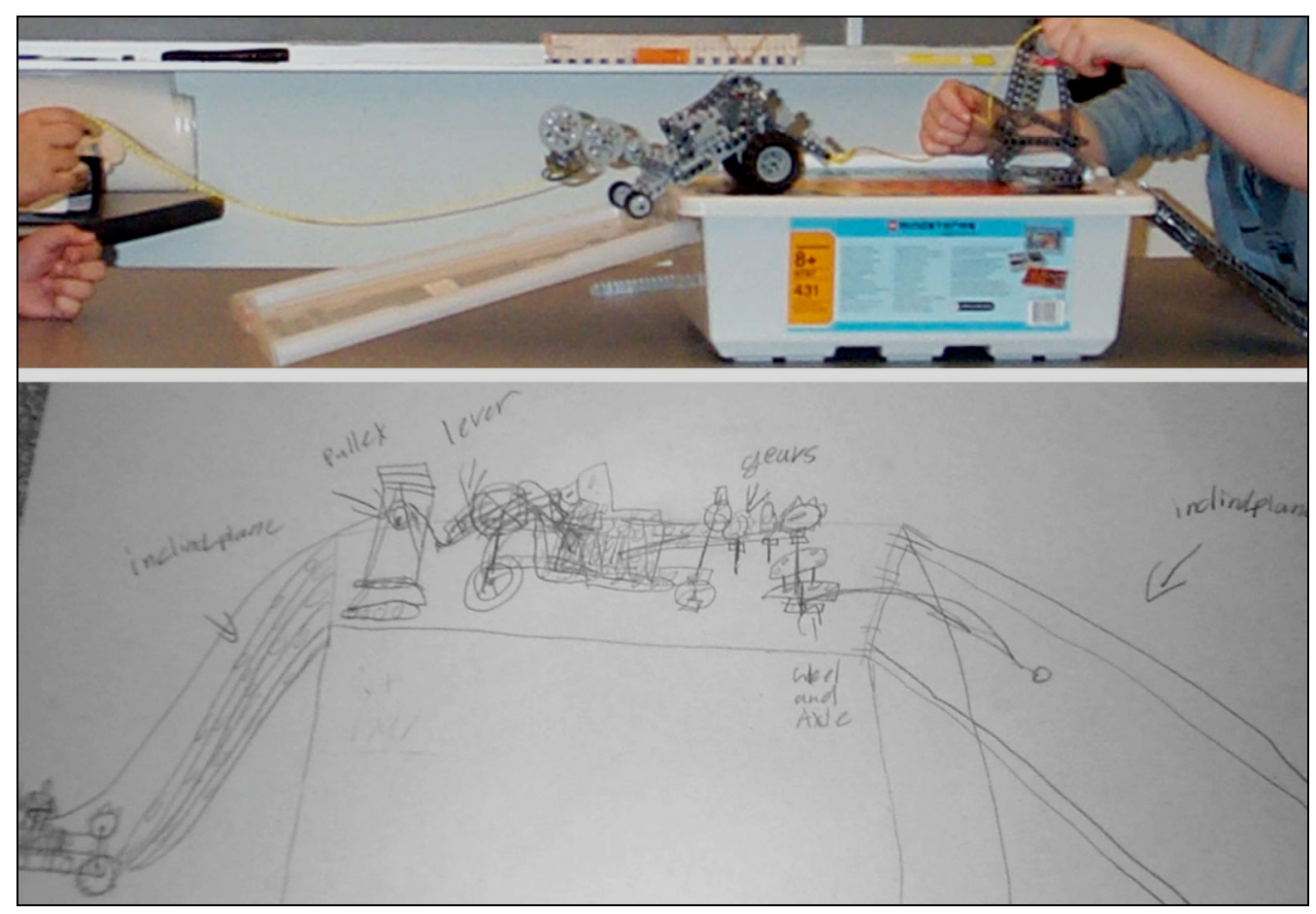

Figure 5. A fourth-grader's people-mover machine and explanatory design poster

\section{Preliminary Curriculum Evaluation Study}

\section{Curriculum Evaluation Methods}

Fourteen third- and fourth-grade teachers from six urban public schools in the northeastern United States volunteered to implement at least one of the four engineering design-based science units. They attended a 30-hour workshop on the content and pedagogy of these units. Before and after unit enactment, their students completed identical paper-and-pencil science content tests. These pre-post tests were also administered in twelve comparison classrooms (from six public and two private schools) of the same grade levels and in the same geographical area. We refer to these as comparison classrooms because their science instruction did not involve LEGO ${ }^{\mathrm{TM}}$ engineering design activities but was intended to meet the same learning objectives (on animal adaptations, simple machines, material properties, or sound). The science curricula taught in the comparison classrooms were chosen by the teachers and their district supervisors. Both engineering-based and comparison teachers were provided with the same set of science learning objectives. There was one science test form for each of the four science domains. The sound and properties of materials tests each had four open-response and five multiple-choice items. The animal adaptations and simple machines tests each had five open-response and five multiplechoice items. Each item addressed one of the science learning objectives in the relevant domain.

In both the intervention and comparison classrooms, the pre-tests were administered within one week of the start of the science units, and the post-tests were administered within one week after unit completion. Because of varying school and district constraints, the teachers' science 
teaching schedules ranged from one science lesson per week to one science lesson every day. Thus, the duration of unit enactment ranged from three weeks to twelve weeks.

The students' responses to the open-response items were scored by two raters according to a 2point rubric. Inter-rater reliability and percent exact match were above 0.8 for all questions. Multiple-choice responses were scored either 0 or 1 point. Total test scores were computed by summing the item scores and dividing by the maximum possible number of points. Thus, all tests scores are represented as percentages.

\section{Curriculum Evaluation Findings}

Overall, paired t-tests revealed significant gains from individual pretests to posttests, across all four domains and both treatment groups. However, there was a main effect of treatment on the magnitude of pre-post gain score. On average, in three of the four science domains (material properties, simple machines, and animal adaptations), the engineering-design-based science students improved significantly more $(\mathrm{p}<.01)$ than the comparison students, as shown in Figure 6. In the domain of sound, the engineering students' average gain was higher than that of the comparison students, but this difference was not significant. However, as shown in Figure 7, the engineering students earned equivalent sound posttest scores, despite having significantly lower sound pretest scores than the comparison students. Thus, after the engineering-design-based curriculum unit on sound, students were able to achieve at levels equal to those of comparison students who had previously been outperforming them. In fact, on the posttests, students in engineering-based science classrooms achieved at statistically equal or higher levels in all domains but animal adaptations. In animal adaptations, the engineering students had significantly lower pre-test and post-test scores than the comparison students, but the engineering students' learning gains were significantly larger.

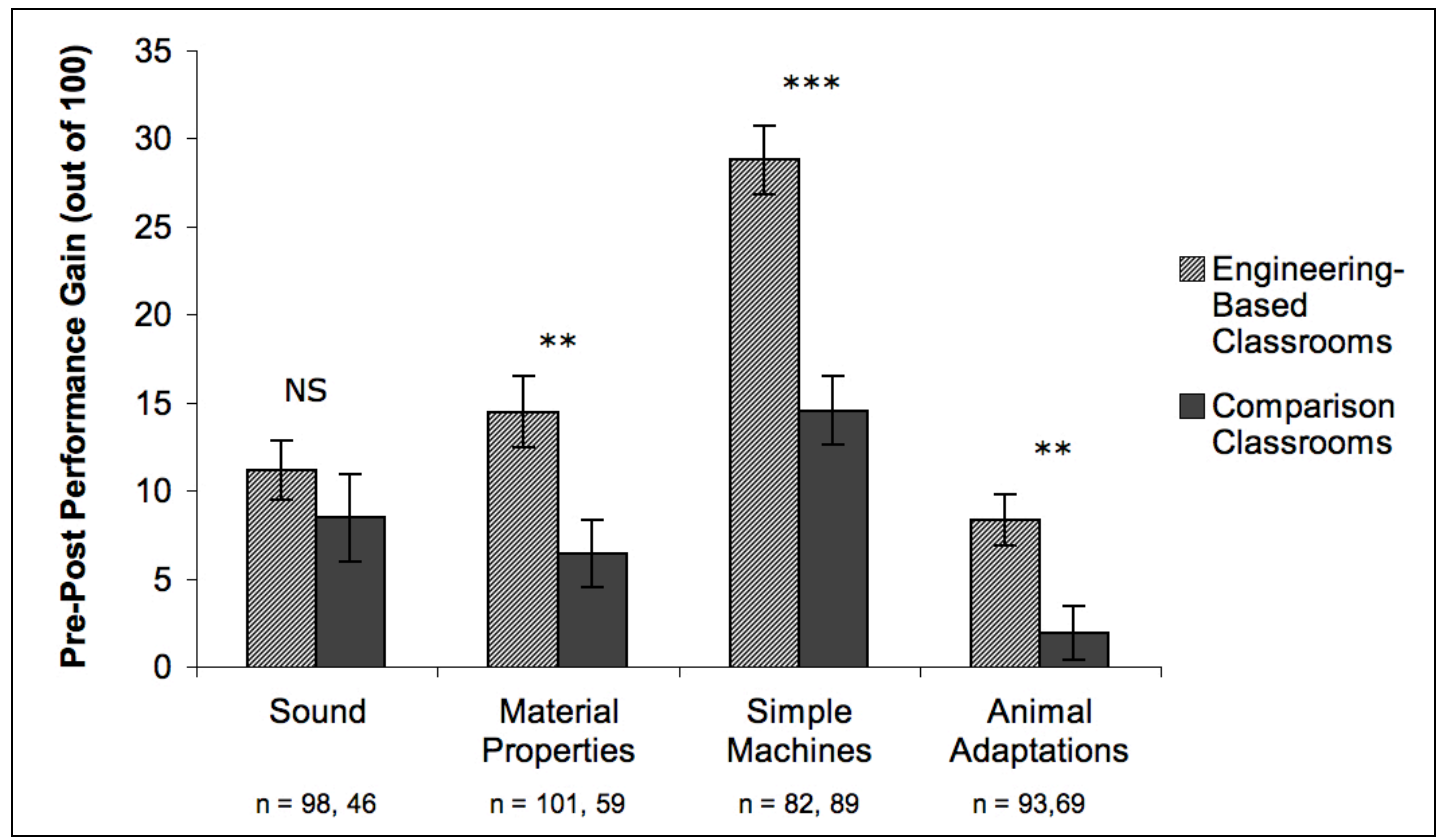

Figure 6. Average learning gains after engineering-design-based and comparison science instruction $(* *=\mathrm{p}<.01, * * *=\mathrm{p}<.001, \mathrm{NS}=\mathrm{p}>.05)$ 


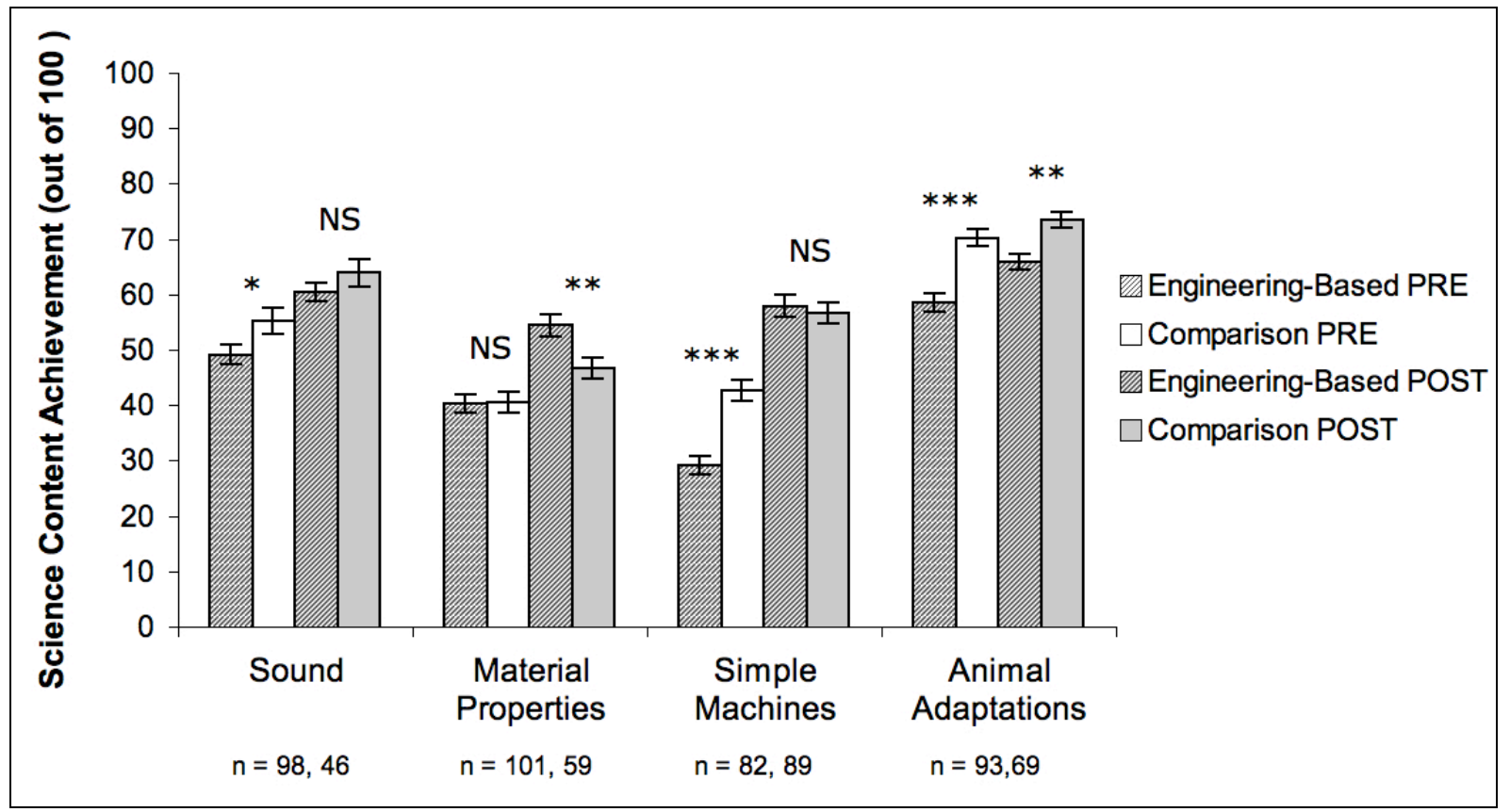

Figure 7. Average pretest and posttest scores in engineering-design-based and comparison classrooms $(*=\mathrm{p}<.05, * *=\mathrm{p}<.01, * * *=\mathrm{p}<.001, \mathrm{NS}=\mathrm{p}>.05)$

\section{$\underline{\text { Discussion and Conclusions }}$}

The overall purpose of our curriculum development endeavor was to investigate the impact of using engineering-design-based activity as the context for science content instruction in the elementary grades. The results of our preliminary curriculum evaluation study suggest that using engineering design as the context for science instruction can facilitate children's learning in the domains of sound, material properties, simple machines, and animal adaptations. The engineering-design-based science students improved more than the comparison students on all four content assessments. However, the results also suggest that the magnitude of the impact of engineering-design-based science curricula varies across science domains. For example, despite earning significantly greater pre/post gains on the animal adaptations test, students in engineering-design-based classrooms had significantly lower animal adaptations posttest scores than comparison students. We speculate that students in the comparison classrooms outperformed students in the engineering-based classrooms on the animal adaptations posttest because this domain is within the discipline of life science, which elementary school teachers have traditionally favored. The engineering-based Design an Animal Model curriculum was effective, but comparison curricula were also effective because elementary-grade teachers have developed strong instructional programs for life science. In contrast, in the discipline of physical science, which includes the sound, material properties, and simple machines domains, there may be more room for design-based science to make an impact on children's learning.

Our results are generally consistent with findings from studies of middle-school and high-school design-based science curricula. Other researchers have found, as we have, that on pre/post written content tests in physical science domains, design-based science students improve significantly more (i.e., earn significantly greater gain scores) than comparison students, ${ }^{3}$ even 
though their average post-tests scores still fall substantially short of the maximum possible score. 3,9 The novel contribution of our study is that it provides evidence that design-based science curricula are associated with significant science content gains by younger, elementaryschool students, and these gains can occur in both physical and life science domains.

In addition to providing evidence that engineering design can enhance younger students' science content learning, the process of creating, testing, revising, and evaluating four elementary-school engineering-design-based science curriculum units has also greatly enriched our understanding of design as it pertains to young science students. When we began our project, we defined engineering design in general as a conscious, deliberate activity of developing and testing a product that performs, under constraints, a specified and desired function for humans and that requires consideration of scientific principles and mathematical concepts. ${ }^{14,36,37}$ This activity necessarily involves purposeful representations, ${ }^{38}$ which may include, among many possibilities, planning documents, preliminary sketches, mathematical computations, mathematical models of processes, models of scientific phenomena, explanation of relevant scientific principles, formal technical drawings, building instructions, and prose artifact descriptions.

Now, better informed by our curriculum development and evaluation efforts, we can propose a characterization of engineering design that is tailored for young science learners. We find that when children engage in engineering design, they need not produce all of the representations mentioned above, but they must engage in the act of representing at each major phase of design: while conceptually planning, while building and testing details, and while communicating the solution. Children's final engineering design representations often take the form of physical prototypes, but these should be tested against the requirements of the design problem and should be accompanied by writing, drawing, or speaking that would enable prototype replication. A child's prototype may be the actual solution to the design problem (e.g., a LEGO ${ }^{\mathrm{TM}}$ musical instrument that really produces multiple pitches) or only a functional model of it (i.e., a LEGOTM robot that retreats in response to light, modeling the behavior of a nocturnal animal).

Cognitive theory and empirical research alike suggest that if children's engineering design is to set the stage for scientific exploration and deepened scientific understanding, then the construction of design artifacts must be accompanied by substantial representation and significant discourse. In other words, students must keep records, in written, drawn, spoken, or other representational form, as they plan, build, test, explain, share, and reflect upon their design artifacts. And teachers must help to establish a discourse of design in the classroom - shared ways of recording, discussing, and making sense.

\section{Bibliography}

1. Fortus, D., Krajcik, J. S., Dershimer, R. C., Marx, R. W., \& Mamlok-Naaman, R. (2005). Design-based science and real-world problem-solving. International Journal of Science Education, 7(3), 855-879.

2. Kolodner, J. L., Camp, P. J., Crismond, D., Fasse, B., Gray, J., Holbrook, J., et al. (2003). Problem-based learning meets case-based reasoning in the middle-school science classroom: Putting Learning by Design (TM) into practice. Journal of the Learning Sciences, 12(4), 495-547. 
3. Mehalik, M. M., Doppelt, Y., Schunn, C. D. (2008). Middle-school science through design-based learning versus scripted inquiry: Better overall science concept learning and equity gap reduction. Journal of Engineering Education, 97(1), 71-85.

4. Baynes, K. (1994). Designerly play. Loughborough, England: Loughborough University of Technology.

5. Pearson, G., \& Young, T. A. (Eds.) (2002). Technically speaking: Why all Americans need to know more about technology. Washington, D.C.: National Academies Press.

6. Layton, D. (1993). Technology's Challenge to Science Education: Cathedral, Quarry or Company Store? Open University Press.

7. National Academy of Engineering and National Research Council. (2009). Engineering in K-12 Education: Understanding the Status and Improving the Prospects. Washington, D.C.: The National Academies Press.

8. Crismond, D. (2001). Learning and using science ideas when doing investigate-and-redesign tasks: A study of naive, novice, and expert designers doing constrained and scaffolded design work. Journal of Research in Science Teaching, 38(7), 791-820.

9. Fortus, D., Dershimer, R. C., Krajcik, J. S., Marx, R. W., \& Mamlok-Naaman, R. (2004). Design-based science and student learning. Journal of Research in Science Teaching, 41(10), 1081-1110.

10. Kolodner, J. L. (2006). Case-Based Reasoning. In K. L. Sawyer (Ed.), The Cambridge handbook of the learning sciences (pp. 225-242). Cambridge: Cambridge University Press.

11. Sadler, P. M., Coyle, H. P., \& Schwartz, M. (2000). Engineering competitions in the middle school classroom: Key elements in developing effective design challenges. Journal of the Learning Sciences, 9(3), 299-327.

12. Roth, W.-M. (1996). Art and artifact of children's designing: A situated cognition perspective. Journal of the Learning Sciences, 5(2), 129-166.

13. Penner, D. E., Lehrer, R., \& Schauble, L. (1998). From physical models to biomechanics: A design-based modeling approach. Journal of the Learning Sciences, 7(3/4), 429-449.

14. Benenson, G. (2001). The unrealized potential of everyday technology as a context for learning. Journal of Research in Science Teaching, 38(7), 730-745.

15. Bers, M. U. (2008). Blocks to robots: Learning with technology in the early childhood classroom. New York: Teachers College Press.

16. Cunningham, C. M., Lachapelle, C., \& Lindgren-Steicher, A. (2005). Assessing elementary school students' conceptions of engineering and technology. Paper presented at the American Society for Engineering Education Annual Conference and Exposition, Portland, Oregon.

17. Papert, S. (1980). Mindstorms: Children, computers, and powerful ideas. New York: Basic Books.

18. Resnick, M., Berg, R., \& Eisenberg, M. (2000). Beyond black boxes: Bringing transparency and aesthetics back to scientific investigation. Journal of the Learning Sciences, 9(1), 7-30.

19. Brophy, S., Klein, S., Portsmore, M., \& Rogers, C. B. (2008). Advancing engineering education in P-12 classrooms. Journal of Engineering Education, 97(2), 1-19.

20. Cejka, E., Rogers, C., \& Portsmore, M. (2006). Kindergarten robotics: Using robotics to motivate math, science, and engineering literacy in elementary school. International Journal of Engineering Education, 22(4), 711-722.

21. Lewis, T. (2006). Design and inquiry: Bases for an accommodation between science and technology education in the curriculum? Journal of Research in Science Teaching, 43(3), 255-281.

22. Penner, D., Giles, N. D., Lehrer, R., \& Schauble, L. (1997). Building functional models: Designing an elbow. Journal of Research in Science Teaching, 34(2), 125-143.

23. Roth, W.-M. (1997). Interactional structures during a grade 4-5 open-design engineering unit. Journal of Research in Science Teaching, 34, 273-302.

24. Roth, W.-M. (2001). Learning science through technological design Journal of Research in Science Teaching, 38(7), 768-790.

25. Brown, J.S., Collins, A., \& Duguid, P. (1989). Situated cognition and the culture of learning. Educational Researcher, 18(1), 32-42.

26. Lave, J., \& Wenger, E. (1991). Situated learning: Legitimate peripheral participation. New York: Cambridge University Press.

27. Hutchins, E. (1995). Cognition in the wild. Cambridge, MA: MIT Press. 
28. Salomon, G., Perkins, D.N., \& Globerson, T. (1991). Partners in cognition: Extending human intelligence with intelligent technologies. Educational Researcher, 20(3), 2-9.

29. Bell, P., \& Winn, W. (2000). Distributed cognitions, by nature and by design. In D. Jonassen \& S. M. Land (Eds.), Theoretical foundations of learning environments. Mahwah, NJ: Lawrence Erlbaum Associates.

30. Grigorenko, E.L., Jarvin, L., Sternberg, R.J. (2002) "School-based tests of the triarchic theory of intelligence: Three settings, three samples, three syllabi." Contemporary Educational Psychology. Vol. 27, 167-208.

31. Krajcik, J. S., \& Blumenfeld, P. C. (2006). Project-based learning. In K. L. Sawyer (Ed.), The Cambridge handbook of the learning sciences (pp. 317-333). Cambridge: Cambridge University Press.

32. Roseman, J. E., Kesidou, S., \& Stern, L. (1997). "Identifying curriculum materials for science literacy: A Project 2061 evaluation tool." Paper prepared for the colloquium Using the National Science Education Standards to guide the evaluation, selection, and adaptation of instructional materials held at the National Research Council, November 10- 12, 1996, Washington, D.C.

33. Sternberg, R. J. (1997). Successful intelligence. New York: Plume.

34. National Research Council. (1996). National science education standards. Washington, D.C.: National Academy Press.

35. Massachusetts Department of Education (2006). Massachusetts science and technology/engineering curriculum framework.

36. Bucciarelli, L. (1994). Designing engineers. Cambridge, MA: MIT Press.

37. Dym, C.L., \& Little, P. (2004). Engineering design: A project-based introduction. John Wiley \& Sons, Inc.

38. Dym, C.L. (1994). Engineering: A synthesis of views. New York: Cambridge University Press.

\section{Acknowledgements}

This work is generously funded by National Science Foundation Grant DRL-0633952, but it does not necessarily represent the policies or positions of the National Science Foundation. We also wish to thank all the students and teachers who make this work possible. They enthusiastically devote time and energy to enacting new curriculum units in their classrooms. 


\section{Appendix A: Curriculum Unit Alignment with Learning Standards for Design a Musical Instrument: The Science of Sound}

\section{Related National, State, and District Learning Standards}

\section{Design a Musical Instrument Learning Objectives \\ By the end of this module, students will be able to:}

1) Recognize that vibrations are responsible for the production of sound

2) Explain how sound vibrations are transmitted through solid, liquid, and gas mediums

3) Distinguish between high pitched and low pitched sounds

4) Indicate that pitch is determined by the speed of vibrations

5) Indicate that volume is determined by the size of vibrations

6) Discuss the effect on pitch of changing the length, tension, or thickness of a vibrating object

7) Predict if a sound would be reflected, absorbed or transmitted through a given medium

8) a) Explain that sound is a form of energy

b) Explain that the amount of energy is determined by the size of the vibrations

9) Combine different materials, shapes, and structures to design and build sound-makers with many different volumes and pitches

10) a) Define engineering design as the process of creating solutions to human problems through creativity and the application of math and science knowledge.

b) List and explain the following steps of the engineering design process:

i. Identifying a problem

ii. Researching possible solutions

iii. Picking the best solution

iv. Building a prototype

v. Testing the prototype

vi. Repeating any steps needed to improve the design

\section{National AAAS Benchmarks}

4.F. $2^{\text {nd }}$ Grade

- Things that make sound vibrate.

\section{National Science Education Standards}

\section{Content Standard B: Position and Motion of} Objects (K-4)

- Sound is produced by vibrating objects. The pitch of the sound can be varied by changing the rate of vibration.

\section{State Frameworks}

\section{Grades 3-5, Strand 3: Physical Science}

- Identify the basic forms of energy (light, sound, heat, electrical, and magnetic). Recognize that energy is the ability to cause motion or create change. - Give examples of how energy can be transferred from one form to another.

- Recognize that sound is produced by vibrating objects and requires a medium through which to travel. Relate the rate of vibration to the pitch of the sound.

\section{District Science Benchmarks}

\section{Sound Learning Standards, Grade 3}

- Recognize that sound is produced by vibrating objects and requires a medium through which to travel. Relate the rate of vibration to the pitch of the sound.

\section{Sound Benchmarks, Grade 3}

- Begin to understand that sound is a form of energy.

- Demonstrate that sound is produced by vibration.

- Begin to recognize that sound can travel through solids, liquids, or gases, but no through completely empty space.

- Describe how to change the pitch of a vibrating string.

- Predict which metal bar when hit will produce the lowest and the highest pitches. 
Appendix B: Curriculum Unit Content Analysis for Design a Musical Instrument: The Science of Sound

\begin{tabular}{|c|c|c|}
\hline Lesson Title & Overview & $\begin{array}{l}\text { Learning Objectives } \\
\text { Students will be able to: }\end{array}$ \\
\hline $\begin{array}{l}1 \\
\text { How can we } \\
\text { make different } \\
\text { sounds? }\end{array}$ & $\begin{array}{l}\text { Students are introduced to the design challenge } \\
\text { of creating LEGO instruments. Then, in a } \\
\text { "mini-design challenge," they explore how to } \\
\text { make different sounds with only two objects (a } \\
\text { plastic cup and plastic spoon). The primary } \\
\text { goal of this lesson is for students to improve } \\
\text { their ability to recognize and articulate what } \\
\text { they notice about different sounds and how the } \\
\text { sounds are produced. }\end{array}$ & $\begin{array}{l}\text { Distinguish between high-pitched } \\
\text { and low-pitched sounds. }\end{array}$ \\
\hline $\begin{array}{l}\text { How can we } \\
\text { make sturdy } \\
\text { instrument } \\
\text { frames? }\end{array}$ & $\begin{array}{l}\text { Students practice using LEGO materials to } \\
\text { build sturdy frames for musical instruments. } \\
\text { They explore the different roles LEGO beams, } \\
\text { plates, axles, connector pegs, and bushings } \\
\text { play in holding LEGO structures together. } \\
\text { Specifically, students are challenged to build } \\
\text { LEGO triangles and rectangular prisms } \\
\text { (boxes). }\end{array}$ & $\begin{array}{l}\text { Combine different shapes and } \\
\text { structures to design and build } \\
\text { frames for sound-makers. }\end{array}$ \\
\hline $\begin{array}{l}3 \\
\text { What makes a } \\
\text { drum make a } \\
\text { sound? }\end{array}$ & $\begin{array}{l}\text { Students make LEGO drums by adding } \\
\text { balloon membranes to their LEGO triangles. } \\
\text { Then, they observe vibrating drum membranes } \\
\text { by sprinkling sugar on the membrane and } \\
\text { watching the sugar bounce up and down. They } \\
\text { perform the vibration observations for both } \\
\text { loud and quiet sounds. }\end{array}$ & $\begin{array}{l}\text { Recognize that vibrations are } \\
\text { responsible for the production of } \\
\text { sound. } \\
\text { Indicate that volume is } \\
\text { determined by the size of sound } \\
\text { vibrations. }\end{array}$ \\
\hline $\begin{array}{l}4 \\
\text { What do } \\
\text { sound } \\
\text { vibrations } \\
\text { travel } \\
\text { through? }\end{array}$ & $\begin{array}{l}\text { This lesson expands on what students learned } \\
\text { in Lesson } 3 \text { about the importance of vibrations } \\
\text { to sound. The focus of the investigation shifts } \\
\text { from the source of sound vibrations to the } \\
\text { transmitter of sound vibrations. Students } \\
\text { continue to use the LEGO drums built in the } \\
\text { previous lesson to explore the transmission of } \\
\text { vibrations through air (gases), solids, and } \\
\text { liquids. They also build pan pipes to prepare } \\
\text { for the investigation to be conducted in Lesson } \\
5 \text {. }\end{array}$ & $\begin{array}{l}\text { Explain how sound vibrations are } \\
\text { transmitted through solid, liquid, } \\
\text { and gas mediums. }\end{array}$ \\
\hline $\begin{array}{l}5 \\
\text { How does size } \\
\text { affect pitch? }\end{array}$ & $\begin{array}{l}\text { This lesson is the first of two that focus on the } \\
\text { pitch of sound. Students explore the effect of } \\
\text { length and thickness on pitch by building a } \\
\text { two-string guitar with a rubber band and a } \\
\text { LEGO frame. The strings have different } \\
\text { thickness to allow students to observe the } \\
\text { effect of thickness on pitch. They use } \\
\text { connector pegs as guitar frets, which allow } \\
\text { them to vary the length of the guitar string } \\
\text { without changing its tension. }\end{array}$ & $\begin{array}{l}\text { Indicate that pitch is determined } \\
\text { by the speed of vibrations. } \\
\text { Discuss the effect on pitch of } \\
\text { changing the length or thickness } \\
\text { of a vibrating object. }\end{array}$ \\
\hline
\end{tabular}




\begin{tabular}{|c|c|c|}
\hline Lesson Title & Lesson Overview & $\begin{array}{l}\text { Lesson Learning Objectives } \\
\text { Students will be able to: }\end{array}$ \\
\hline $\begin{array}{c}6 \\
\text { How does } \\
\text { tension affect } \\
\text { pitch? }\end{array}$ & $\begin{array}{l}\text { This lesson is the second of two that focus on } \\
\text { the pitch of sound. Students explore the effect } \\
\text { of tension on pitch by building a one-string } \\
\text { guitar with a rubber band, LEGO frame, and } \\
\text { LEGO motor. They wind one end of the } \\
\text { rubber band around an axle attached to the } \\
\text { LEGO motor. The motor allows them to vary } \\
\text { the tension of the guitar string without } \\
\text { changing its length or width. }\end{array}$ & $\begin{array}{l}\text { Indicate that pitch is determined } \\
\text { by the speed of vibrations. } \\
\text { Discuss the effect on pitch of } \\
\text { changing the tension of a } \\
\text { vibrating object. }\end{array}$ \\
\hline $\begin{array}{l}7 \\
\text { What happens } \\
\text { to sound } \\
\text { before it } \\
\text { reaches our } \\
\text { ears? }\end{array}$ & $\begin{array}{l}\text { Students build a LEGO rattle, or maraca, and } \\
\text { measure its noise output with a LEGO NXT } \\
\text { sound sensor. They investigate what happens } \\
\text { when they muffle the maraca with their hands. } \\
\text { The hand muffler activity is intended to help } \\
\text { students explore how sound can be absorbed, } \\
\text { reflected, or transmitted as it travels away } \\
\text { from its source. }\end{array}$ & $\begin{array}{l}\text { Predict if a sound will be } \\
\text { reflected, absorbed, or } \\
\text { transmitted through a given } \\
\text { medium. } \\
\text { Explain that sound is a form of } \\
\text { energy. }\end{array}$ \\
\hline $\begin{array}{l}\quad 8 \\
\text { How can we } \\
\text { make one } \\
\text { instrument } \\
\text { with three } \\
\text { pitches? }\end{array}$ & $\begin{array}{l}\text { Students design and build their own LEGO } \\
\text { instruments. They use what they have learned } \\
\text { by building the previous 'research' } \\
\text { instruments. However, their instrument must } \\
\text { be a new invention, and it must play at least } \\
\text { three different pitches. Students will be asked } \\
\text { to demonstrate these instruments by using } \\
\text { them to play a song for the class. }\end{array}$ & $\begin{array}{l}\text { Combine different materials, } \\
\text { shapes, and structures to design } \\
\text { and build sound-makers with } \\
\text { many different volumes and } \\
\text { pitches. } \\
\text { Define engineering design as the } \\
\text { process of creating solutions to } \\
\text { human problems through } \\
\text { creativity and the application of } \\
\text { math and science knowledge, and } \\
\text { list and explain the steps of the } \\
\text { engineering design process. }\end{array}$ \\
\hline $\begin{array}{l}9 \\
\text { What can we } \\
\text { do to make } \\
\text { high, medium, } \\
\text { and low } \\
\text { pitches? }\end{array}$ & $\begin{array}{l}\text { Students complete posters that explain how } \\
\text { their instrument makes at least three different } \\
\text { pitches. Then, the culminating event of the } \\
\text { module is an engineering design expo in which } \\
\text { students demonstrate their instruments and } \\
\text { explain the design features that produced the } \\
\text { three different pitches. }\end{array}$ & $\begin{array}{l}\text { Combine different materials, } \\
\text { shapes, and structures to design } \\
\text { and build sound-makers with } \\
\text { many different volumes and } \\
\text { pitches. } \\
\text { Define engineering design as the } \\
\text { process of creating solutions to } \\
\text { human problems through } \\
\text { creativity and the application of } \\
\text { math and science knowledge, and } \\
\text { list and explain the steps of the } \\
\text { engineering design process. }\end{array}$ \\
\hline
\end{tabular}

